\title{
Influence of Simulated Grazing (Clipping) on Pinegrass Growth
}

\author{
DARRYL G. STOUT, A. McLEAN, B. BROOKE, AND J. HALL
}

\begin{abstract}
Pinegrass (Calamagrostis rubescens) was clipped at several frequencies and intensities at three sites in the Douglasfir (Pseudotsuga menziesii) zone of British Columbia. The effect of herbage removal on pinegrass vigor could be assessed by measuring tiller height, tiller number $/ \mathrm{m}^{2}$, or yield $/ \mathrm{m}^{2}$ the year following clipping. Variability in pinegrass cover at a site necessitated measuring initial plot cover so than an analysis of covariance could be done to statistically isolate its effect. Initial pinegrass cover did not affect the tiller height measurement however. Plant vigor decrease due to herbage removal depended upon the degree and time of herbage removal and either the environmental conditions during the year of clipping or plant history before herbage removal or both. Pinegrass vigor was most sensitive to clipping during the last half of July and early in August. This is the time when pinegrass growth is slowing down and summer dormancy is setting in. It is recommended that pinegrass be grazed for a short time while it is actively growing (early in June) and then later when mid-summer dormancy is well established (August) to maintain its vigor. If pinegrass must be grazed during July, then it should be rested during July the following year. Further work is required to establish grazing schemes that will maximize animal production and maintain adequate pinegrass vigor.
\end{abstract}

Grazing normally decreases plant growth and vigor (Crider 1955; Trlica 1977): the more frequent or intense the grazing the greater the decrease. However, the degree of growth and vigor decrease also depends on plant growth stage when grazed (Stoddart and Smith 1955; Buwai and Trlica 1977 a \& b) and on environmental (aid and soil) conditions (Feltner and Massengale 1965; Oswalt et al. 1959). The grazing effect may be related to decreased plant photosynthetic potential, which in turn results in decreased carbohydrate storage (Buwai and Trlica 1977 a \& b), cessation of root growth or even root death (Crider 1955; Branson 1956), decreased rate of leaf initiation and growth (Davidson and Milthorpe 1966), or a combination of these factors. Removal of growing points may also cause decreased plant vigor (Branson 1953). A decreased competitive ability of grazed plants compared to nongrazed plants results in further weakening of the grazed plants (Mueggler 1972).

Under certain conditions grazing can increase plant growth (Eck et al. 1975; Gupta 1977). This increased growth may be due to: increased tiller development resulting from

\footnotetext{
Authors are forage physiologist, range ecologist, forage technician, Agriculture Canada, Range Research Station, Kamloops, B.C. V2B 8A9, Canada, and statistician, Agriculture Canada Research Station, 6660 N.W. Marine Drive, Vancouver, B.C. V6T 1X2, Canada.

Authors would like to thank Dr. D.A. Quinton for his valuable criticism of the manuscript.

Manuscript received December 27, 1978.
}

removal of apical dominance (Leopold 1949), increased photosynthesis owing to better light penetration or sink size (Deinum 1976), increased soil temperature (Sharrow and Wright 1977) or possibily even to saliva supplying chemicals which stimulate plant growth. However, Trlica (1977) cautions that early reports of grazing stimulating production of arid and semiarid rangeland plants may be a result of poor experimental design.

About 6 million hectares of the Douglasfir Pseudotsugamenziesii) zone of interior British Columbia are utilized for summer grazing (Tisdale and McLean 1957). Pinegrass (Calamagrostis rubescens) occupies up to $80 \%$ of the ground area and provides approximately $50 \%$ of the available forage by weight in the Douglasfir zone (Tisdale and McLean 1957). Thus it is important to determine how much grazing pinegrass can tolerate and when pinegrass is most susceptible to grazing. A preliminary clipping trial on pinegrass has been done near Kamloops by Freyman (1970). This study entailed clipping pinegrass, at one site to one height $(15 \mathrm{~cm})$ at different frequencies, for four consecutive years. A significant effect of clipping was not detected until the 3rd year. It was found that dry matter yield was not affected if herbage removal was not initiated until after June 30 or if herbage was removed only once before June 30 .

In this paper we report on an expanded study of the effect of clipping on pinegrass growth. One objective was to determine if the lack of an early effect in Freyman's study was more likely due to high grazing resistance of pinegrass or to favourable environmental conditions. The effect of different defoliation treatments on winter survival of Lolium multiflorum varied with the severity of the winter (Hides 1978). Clipping was also done at three sites differing in elevation and tree cover to obtain more applicable results as to the critical period of grazing. We evaluated tiller height and tiller number $/ \mathrm{m}^{2}$, in addition to yield, as measures of plant vigor. We did not include such vigor measures as clump basal area and flowering culm production because they are not applicable to this rhizomatous and infrequently flowering species.

\section{Methods and Materials}

\section{Study Area}

The study sites were within a $3.5-\mathrm{km}$ radius of Pass Lake which is approximately $22 \mathrm{~km}$ northwest of Kamloops. Site locations were chosen in different plant communities representative of the Douglasfir zone, but on each the dominant ground cover species was pinegrass. Separate clipping trials, each on a new set of plots, were conducted in 1974 and 1975.

The Pass Lake site was in a relatively open, level area on a 
densely treed south-facing slope overlooking the lake, at $1,006 \mathrm{~m}$ elevation. The tree cover was a predominantly mature stand of Douglasfir. The 2 years' trials were located within $16 \mathrm{~m}$ of each other.

The Poison Creek site was approximately $3 \mathrm{~km}$ north of Pass Lake, situated on a $12 \%$ west-facing slope at $1,189 \mathrm{~m}$ elevation. The tree cover was a moderately open stand of lodgepole pine (Pinus contorta), trembling aspen (Populus tremuloides) and Douglasfir. The two trials were $36 \mathrm{~m}$ apart.

The 1974 Opax Mountain site was $3 \mathrm{~km}$ south of Pass Lake on a $20 \%$ southfacing slope at 1,128 m elevation. The tree cover was an open, logging-thinned stand of mature Douglasfir. For the 1975 trial a new site was chosen on this mountain, because it was felt that the original site too closely resembled the one at Pass Lake. The second site was $2 \mathrm{~km}$ west of the first on an $18 \%$ south-facing slope at 1,128 $\mathrm{m}$ elevation, in a dense lodgepole pine stand.

\section{Plot Design}

At each site, $1-\mathrm{m}^{2}$ plots were laid out in a complete random design, with nine treatments and four replicates. Each plot was located on an almost-pure stand of pinegrass. Within each plot a $0.2-\mathrm{m}^{2}$ subplot was marked with spikes, over which a metal frame could be fitted to facilitate sequential observations of the same area.

\section{Treatments and Plant Measurements}

A preliminary survey of cattle grazing on pinegrass (79 observations, on Opax Mountain) revealed that the stubble height ranged from 8 to $23 \mathrm{~cm}$. Forty two percent of the plants were grazed to $10 \pm 2 \mathrm{~cm}$, and $43 \%$ were grazed to $15 \pm 2 \mathrm{~cm}$. In the present study, light, moderate, and heavy grazing intensities were simulated by clipping plots biweekly, to 15,10 , and $5 \mathrm{~cm}$ respectively, during the period from May 15 to September 15. As well, biweekly clipping to $5 \mathrm{~cm}$ was done during different portions of this time period, to determine when pinegrass is most sensitive to herbage removal. The specific periods and heights of clipping for each of the nine treatments are indicated in the tables.

Number of tillers within each $1 / 5-\mathrm{m}^{2}$ subplot was recorded at the time clipping treatments were initiated to evaluate plot variability and to serve as a covariate for an analysis of covariance. In 1974 growth removed at each clipping was collected, oven-dried (60C) and weighed for cumulative yield determination for the treatment clipped to $5 \mathrm{~cm}$ from May 15 to September 15. The effect of clipping in 1974 was evaluated in August 1975 by counting tillers in the $1 / 5-\mathrm{m}^{2}$ subplot, measuring average tiller height within the $1-\mathrm{m}^{2}$ plot and measuring the season's production by harvesting the plot to ground level. The effect of the 1975 clip was evaluated by counting tillers in May of 1976.

\section{Measurement of Environmental Conditions}

Rain gauges and Stevenson screens containing monthly thermographs (model 251C or 252C Wilh. Lambrecht Ltd., Gottingen, West Germany), were maintained at each site from June 1 to October 31 to monitor rainfall and air temperature. Soil temperature was taken at 10,25 , and 50 -cm depths, biweekly from May 15 to September 30 with a battery operated telethermometer (model 43TE, Yellow Springs Inst. Co. Inc., Yellow Springs,
Ohio). Soil samples, for gravimetric moisture content determination, were taken biweekly at 5, 10, and $25 \mathrm{~cm}$ depths.

The canopy cover at the three 1975 clip locations was measured in August 1978, using a spherical densiometer (model A, Paul E. Lemmon, Forest Densiometers, 2413 Kenmore St., Arlington, Virginia). Measurements were taken at eight locations per site. Percent overstory density was $77 \pm 8(x \pm S D)$ at Pass Lake, 63土5 at Poison Creek and $84 \pm 1$ at Opax Mountain.

\section{Results}

\section{Variability of Pinegrass Cover at a Site}

Initial tiller counts on the 36 plots at each site indicated high pinegrass cover variability at all sites (Table 1). The number of plots required to obtain an allowable error equal to $10 \%$ of the mean (Snedecor and Cochran 1967) varied between 34 and 84 depending upon the particular site (Table 1). Practically, it would not have been possible to use such a large number of plots for each clipping treatment. Thus four plots per treatment were used and treatment effects were determined using analysis of covariance with initial tiller

\section{Effect of Clipping on Pinegrass Growth}

Dry matter yield, tiller height and number of tillers were measured in 1975 on plots clipped during 1974. Yield was affected by both site and treatment $(P \leq 0.01)$. However, differences among treatment yields were independent of site and therefore the results can be described by a single set of adjusted means (Table 2). All clipping treatments decreased yield. Those causing the least were $\mathrm{L}$ and $\mathrm{H}_{1}$. The adjusted mean yield for Opax Mountain $\left(22.8 \mathrm{~g} / \mathrm{m}^{2}\right)$ was lower than that for Pass Lake $\left(27.9 \mathrm{~g} / \mathrm{m}^{2}\right)$ or Poison Creek $\left(27.0 \mathrm{~g} / \mathrm{m}^{2}\right)$ by Duncan's test ( $P \leq 0.05$ ).

Tiller height was affected by site and treatment $(P \leq 0.01)$, but differences among treatments were independent of site so that the results could be described by a single set of adjusted means (Table 2). All clipping treatments affected tiller height. $\mathrm{H}_{6}$ was the most severe clipping treatment and $\mathrm{L}, \mathrm{H}_{1}$ and $\mathrm{H}_{3}$ the least severe treatments. The adjusted mean tiller height at Opax Mountain $(27.2 \mathrm{~cm})$ was lower than at Pass Lake $(32.1 \mathrm{~cm})$ or Poison Creek $(30.9 \mathrm{~cm})$ by Duncan's Test $(P \leq 0.05)$. Tiller height was not significantly related to the initial tiller count.

Tiller number was affected by site and treatment (Table 3). As found for yield and tiller height, all 1974 clipping treatments affected tiller number the following year. The combined data indicate that the most severe treatments were $\mathrm{H}_{4}, \mathrm{H}_{5}$, and $\mathrm{H}_{6}$ (Table 3 ). Other clipping treatments had approximately the same effect on tiller number. The site effect is demonstrated by the fact that the clipping treatments had no significant effect at Poison Creek, but did at Pass Lake and Opax Mountain (Table 3).

Table 1. Initial number of tillers per $\mathrm{m}^{2}$ at the experimental sites, calculated from 36 plots at each site.

\begin{tabular}{|c|c|c|c|c|c|}
\hline \multirow[b]{2}{*}{ Site } & \multirow[b]{2}{*}{ Experiment } & \multicolumn{2}{|c|}{ Number of tillers } & \multirow{2}{*}{$\begin{array}{l}\text { Coefficient } \\
\text { of variation }\end{array}$} & \multirow[b]{2}{*}{$\left(\mathrm{n}\right.$ for $\left.\mathrm{L}=0.1_{\mathrm{x}}\right)$} \\
\hline & & $x$ & $S D$ & & \\
\hline Opax Mountain & $\begin{array}{l}1974 \text { clip } \\
1975 \text { clip }\end{array}$ & $\begin{array}{l}895 \\
470\end{array}$ & $\begin{array}{l}320 \\
140\end{array}$ & $\begin{array}{l}36 \\
30\end{array}$ & $\begin{array}{l}51 \\
84\end{array}$ \\
\hline Poison Creek & $\begin{array}{l}1974 \text { clip } \\
1975 \text { clip }\end{array}$ & $\begin{array}{r}720 \\
1120\end{array}$ & $\begin{array}{l}215 \\
320\end{array}$ & $\begin{array}{l}30 \\
29\end{array}$ & $\begin{array}{l}36 \\
34\end{array}$ \\
\hline Pass Lake & $\begin{array}{l}1974 \text { clip } \\
1975 \text { clip }\end{array}$ & $\begin{array}{l}840 \\
885\end{array}$ & $\begin{array}{l}350 \\
300\end{array}$ & $\begin{array}{l}42 \\
34\end{array}$ & $\begin{array}{l}69 \\
46\end{array}$ \\
\hline
\end{tabular}

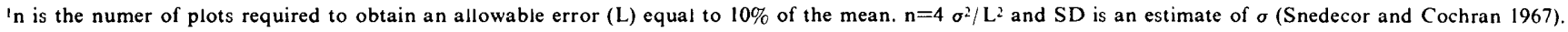


Table 2. Influence of simulated grazing (clipping) during 1974 on pinegrass yield and tiller height measured in 1975.

\begin{tabular}{|c|c|c|c|c|c|}
\hline Treatment code & $\begin{array}{c}\text { Clipping height } \\
(\mathrm{cm})\end{array}$ & $\begin{array}{l}\text { Period during which } \\
\text { plots were clipped } \\
\text { every } 2 \text { weeks }\end{array}$ & $\begin{array}{l}\text { Growth periods } \\
\text { clipped } 1\end{array}$ & $\begin{array}{l}\text { Yield } 2 \\
(\mathrm{~g} \text { dry wt/ m²) }\end{array}$ & $\begin{array}{l}\text { Tiller height } \\
(\mathrm{cm})\end{array}$ \\
\hline Standard Error & $\begin{array}{c}\text { none } \\
15 \\
10 \\
5 \\
5 \\
5 \\
5 \\
5 \\
5\end{array}$ & \begin{tabular}{l}
\multicolumn{1}{c}{ none } \\
May 15-Sept. 15 \\
May 15-Sept. 15 \\
May 15-Sept. 15 \\
July 1-Sept. 15 \\
May 15-Aug. 1 \\
July15-Aug. 15 \\
May 15-July 1 \\
Aug. 15-Sept. 15
\end{tabular} & $\begin{array}{l}\text { G, Ds, R } \\
\text { G, Cs, R } \\
\text { G, Ds, R } \\
\text { G, Ds, R } \\
\text { G, Cs } \\
\text { G, Ds } \\
\text { G } \\
\quad \text { Ds, R }\end{array}$ & $\begin{array}{l}52.4 a \\
29.1 b c \\
24.6 c d \\
17.3 e \\
20.0 d e \\
15.6 e \\
26.1 c d \\
25.5 c d \\
32.6 b \\
2.1\end{array}$ & $\begin{array}{l}35.0 a \\
31.7 b \\
28.9 d \\
25.4 e \\
29.2 c d \\
27.8 d \\
28.2 d \\
31.3 b c \\
32.7 b \\
0.8\end{array}$ \\
\hline
\end{tabular}

'G, Ds, and $R$ refer to the growth, summer dormancy and regrowth periods.

2Plots were clipped at three sites (Pass Lake, Opax Mountain and Poison Creek). The treatment differences were independent of site location so only the combined data is shown. The means have been adjusted using number of tillers before treatment. Values, within a column, followed by different letters are significantly different at $P \leq 0.05$ (Duncan's
multiple range test).

In 1976 , only number of tillers $/ \mathrm{m}^{2}$ was measured on the plots clipped during 1975. As observed for the $1974 \mathrm{clip}$, tiller number was affected by site and treatment (Table 3 ). From the combined data the most severe treatment was $\mathrm{H}_{4}$ and the least severe treatments were $\mathrm{L}$ and $\mathrm{H}_{1}$. A significant effect of clipping did not occur at Opax Mountain but did occur at Pass Lake and Poison Creek.

Pinegrass growth is episodic rather than continuous (Fig. 1). Most growth $(G)$ occurs during the period of May 15 to approximately August 1. Following growth, summer dormancy (Ds) occurs. In late August or early September, depending upon site and year, regrowth (R) may occur. Following fall regrowth, pinegrass enters winter dormancy (Dw). Initiation of growth in the spring depends upon favourable temperature conditions and initiation of summer dormancy appears to depend upon soil water depletion since fall regrowth is correlated with fall rains. Because these growth periods are largely related to environmental rather than plant characteristics, the growth pattern determined from four plots should be characteristic of the site even though four plots were not sufficient to characterize the yield of a site (Table 1). Our treatments $\mathrm{L}, \mathrm{M}, \mathrm{H}_{4}$, and $\mathrm{H}_{6}$ occurred during the periods $G$, Ds, and $R$ of the pinegrass growth cycle. However, treatment $\mathrm{H}_{4}$ was different from the other three treatments in that it only occurred during the latter part of the $\mathrm{G}$ period. $\mathrm{H}_{5}$ and $\mathrm{H}_{2}$ occurred during the periods $\mathrm{G}$ and Ds; however, $\mathrm{H}_{2}$ occurred only during the latter part of period $\mathrm{G}$. Treatment $\mathrm{H}_{3}$ occurred during the period $\mathrm{G}$ and treatment $\mathrm{H}_{1}$ occurred during the Periods Ds and $R$.

\section{Contribution of Tiller Number and Size to Yield}

The relationship of pinegrass yield to tiller number and height (a measure of tiller size) is described by the following equation:

$$
\text { Yield } \left./ \mathrm{m}^{2}=\mathrm{a}(\mathrm{T})+0.003234 \text { (tiller number } / \mathrm{m}^{2}\right)(\text { tiller height) }
$$

where tiller height is expressed in $\mathrm{cm}$ and the constant a (T) depends upon the clipping treatment (Table 4). The square

Table 3. Influence of simulated grazing (clipping) on the average number of pinegrass tillers per square meter at three sites.

\begin{tabular}{|c|c|c|c|c|c|c|c|}
\hline \multirow[b]{2}{*}{$\begin{array}{l}\text { Year } \\
\text { clipped } \\
\end{array}$} & \multirow[b]{2}{*}{$\begin{array}{l}\text { Treatment } \\
\text { code }\end{array}$} & \multirow{2}{*}{$\begin{array}{c}\text { Clipping height } \\
(\mathrm{cm})\end{array}$} & \multirow{2}{*}{$\begin{array}{l}\text { Period during which } \\
\text { plots were clipped } \\
\text { every } 2 \text { weeks }\end{array}$} & \multicolumn{4}{|c|}{ Site ${ }^{1}$} \\
\hline & & & & $\begin{array}{l}\text { Opax } \\
\text { Mountain }\end{array}$ & $\begin{array}{l}\text { Poison } \\
\text { Creek }\end{array}$ & $\begin{array}{l}\text { Pass } \\
\text { Lake }\end{array}$ & Combined \\
\hline $1974 !$ & & & & & & & \\
\hline Standard Error & $\begin{array}{l}\mathrm{C} \\
\mathrm{L} \\
\mathrm{M} \\
\mathrm{H}_{6} \\
\mathrm{H}_{4} \\
\mathrm{H}_{5} \\
\mathrm{H}_{2} \\
\mathrm{H}_{3} \\
\mathrm{H}_{1}\end{array}$ & $\begin{array}{r}- \\
15 \\
10 \\
5 \\
5 \\
5 \\
5 \\
5 \\
5\end{array}$ & $\begin{array}{l}\text { Control (no clip) } \\
\text { May 15-Sept. 15 } \\
\text { May 15-Sept. } 15 \\
\text { May 15-Sept. 15 } \\
\text { July 1-Sept. 15 } \\
\text { May 15-Aug. 1 } \\
\text { July 15-Aug. 15 } \\
\text { May 15-July I } \\
\text { Aug. 15-Sept. 15 }\end{array}$ & $\begin{array}{l}842 a \\
524 a b \\
716 a b \\
552 a b \\
564 a b \\
389 b \\
706 a b \\
598 a b \\
872 a \\
108\end{array}$ & $\begin{array}{c}1018 a \\
974 a \\
983 a \\
858 a \\
653 a \\
779 a \\
948 a \\
968 a \\
904 a \\
108\end{array}$ & $\begin{array}{l}1338 a \\
1146 a b \\
890 b c \\
547 c d \\
800 b c \\
338 d \\
884 b c \\
665 c d \\
792 b c \\
108\end{array}$ & $\begin{array}{c}1066 a \\
882 b \\
863 b c \\
652 d e \\
672 c d \\
502 e \\
846 b c \\
744 b c \\
856 b c \\
62\end{array}$ \\
\hline Standard Error & $\begin{array}{l}\mathrm{C} \\
\mathrm{L} \\
\mathrm{M} \\
\mathrm{H}_{6} \\
\mathrm{H}_{4} \\
\mathrm{H}_{5} \\
\mathrm{H}_{2} \\
\mathrm{H}_{3} \\
\mathrm{H}_{1}\end{array}$ & $\begin{array}{r}- \\
15 \\
10 \\
5 \\
5 \\
5 \\
5 \\
5 \\
5\end{array}$ & $\begin{array}{l}\text { Control (no clip) } \\
\text { May 15-Sept. 15 } \\
\text { May 15-Sept. 15 } \\
\text { May 15-Sept. 15 } \\
\text { July 1tSept. } 15 \\
\text { May 15-Aug. 1 } \\
\text { July15-Aug. 15 } \\
\text { May 15-July 1 } \\
\text { Aug. 15-Sept. } 15\end{array}$ & $\begin{array}{l}869 a \\
832 a \\
803 a \\
617 a \\
635 a \\
662 a \\
674 a \\
939 a \\
786 a \\
122 \\
\end{array}$ & $\begin{array}{l}926 a \\
559 a b \\
152 b \\
448 b \\
172 b \\
376 b \\
500 a b \\
529 a b \\
560 a b \\
122 \\
\end{array}$ & $\begin{array}{l}1014 a \\
900 a b \\
754 a b \\
530 b \\
622 a b \\
558 b \\
726 a b \\
607 a b \\
856 a b \\
122 \\
\end{array}$ & $\begin{array}{l}936 a \\
764 a b \\
570 b c \\
532 c b \\
476 d \\
532 c d \\
634 b c \\
692 b c \\
734 a b \\
70 \\
\end{array}$ \\
\hline
\end{tabular}

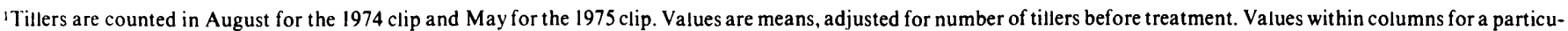
lar year, followed by different letters are significantly different at $P \leq 0.05$ (Duncan's multiple range test). 


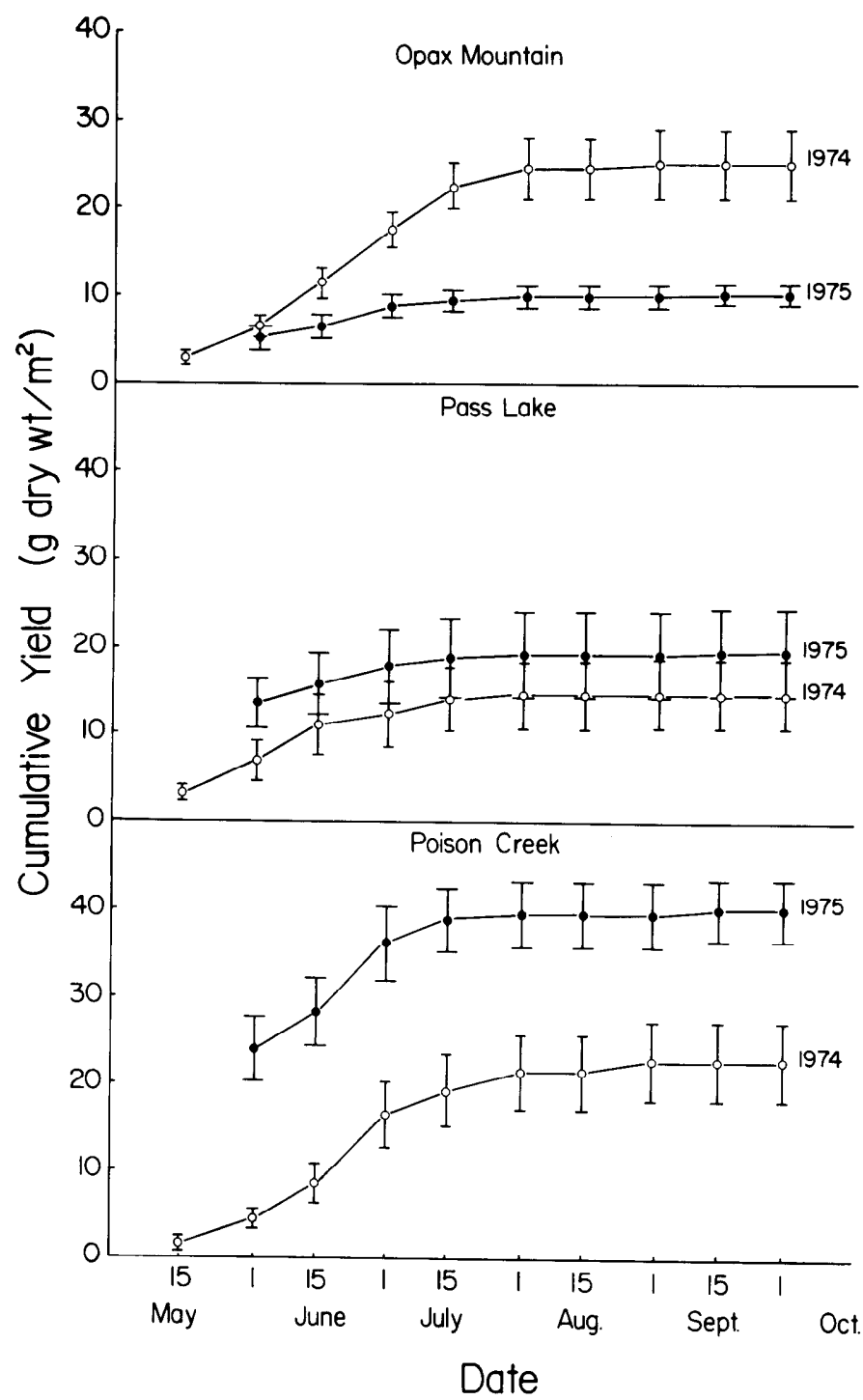

Fig. 1. Pinegrass growth pattern at the three sites during 1974 and 1975. Values are $\mp S E$ ( $n=4$ plots).

of the multiple correlation coefficient for this equation is 0.77 . After yield was adjusted for treatment, its partial correlation coefficient with tiller number $/ \mathrm{m}^{2}$ was 0.72 and with tiller height was 0.35 . Clipping decreased the value of a (T) (Table 4).

Environmental Conditions during the Years of Clipping

Based on mean daily maximum temperature and rainfall (Table 5), 1974 was hotter and dryer than 1975.
In 1974 Pass Lake had the highest mean daily maximum temperature and Poison Creek the lowest (Table 5). In 1974 the mean daily minimum temperature was higher at Opax Mountain than at Pass Lake or Poison Creek. Rainfall was lowest at Pass Lake and highest at Poison Creek during 1974

In 1975 Pass Lake had a higher mean daily maximum temperature than Poison Creek or Opax Mountain (Table 5) and Opax Mountain had the lowest rainfall and Pass Lake the highest rainfall. Soil temperature data reveal that Pass Lake was warmer than the other two sites in 1975 (Table 6).

Soil drying curves for 1975 indicated no large differences between sites (data not shown). From June 1 to October 1, soil moisture at all three sites decreased from $50 \%$ to $8 \%$ at 5 $\mathrm{cm}$, from $40 \%$ to $9 \%$ at $10 \mathrm{~cm}$, and from $22 \%$ to $9 \%$ at $25 \mathrm{~cm}$.

\section{Discussion}

One year of clipping to $15 \mathrm{~cm}$ (simulating light grazing) decreased pinegrass vigor significantly in 1974 (tiller number decreased 17\%) but not in 1975 (Table 3). Conditions during the year 1974 were hotter and dryer than those in 1975, which may account for light grazing having a significant effect in 1974 but not in 1975. One year of clipping to $5 \mathrm{~cm}$ (simulating heavy grazing) decreased pinegrass vigor in both 1974 and 1975 (tiller number decreased $39 \%$ and $43 \%$ respectively) according to the combined data (Table 3). However when data for individual sites are considered, heavy grazing had no detectable effect at Poison Creek in 1974, or at Opax Mountain in 1975.

To speculate, the higher rainfall and lower maximum temperature at Poison Creek during 1974 (Table 5) may partly explain the lack of a clipping effect there. Weather conditions, however, cannot account for the lack of an effect at Opax Mountain in 1975. Perhaps a difference in plant health (dependent on past history) at the Opax Mountain site used in 1975 compared to that used in 1974 is responsible for the lack of an effect at Opax Mountain in 1975. Experimental error was similar at all sites (Table 3) and so cannot explain the site differences. Even though the specific cause for the lack of an effect at Poison Creek in 1974 and at Opax Mountain in 1975 is not known, it can be concluded that environmental conditions and/or previous plant history influence plant response to herbage removal. Therefore it is not possible to simply assign a level of grazing resistance to a plant species without considering the environment in which it will be growing (Hides 1978). It is necessary to conduct plant evaluation trials at more than one site and for more than 1 year. The lack of effect of clipping to $15 \mathrm{~cm}$ during the first 2 years of Freyman's (1970)

Table 4. Influence of simulated grazing (clipping) on the value of the constant a(T) in the equation relating yield to number and height pinegrass tillers.

\begin{tabular}{lclll}
\hline \hline Treatment code & $\begin{array}{c}\text { Clipping height } \\
(\mathrm{cm})\end{array}$ & $\begin{array}{l}\text { Period during which } \\
\text { plots were clipped } \\
\text { every 2 weeks }\end{array}$ & $\begin{array}{l}\text { Growth periods } \\
\text { clipped }\end{array}$ & $\mathrm{a}(\mathrm{T})$ \\
\hline $\mathrm{C}$ & & & May 15-Sept. 15 & \\
$\mathrm{L}$ & 15 & May 15-Sept. 15 & G, Ds, R & 27.5 \\
$\mathrm{M}$ & 10 & May 15-Sept. 15 & G, Ds, R & 25.4 \\
$\mathrm{H}_{6}$ & 5 & July 1-Sept. 15 & G, Ds, R & 21.9 \\
$\mathrm{H}_{4}$ & 5 & May 15-Aug. 1 & G, Ds \\
$\mathrm{H}_{5}$ & 5 & July 15-Aug. 15 & G, Ds & 23.2 \\
$\mathrm{H}_{2}$ & 5 & May 15-July 1 & Ds, R & 27.0 \\
$\mathrm{H}_{3}$ & 5 & Aug. 15-Sept. 15 & & 30.1 \\
$\mathrm{H}_{1}$ & 5 & & & \\
\hline
\end{tabular}

'G, Ds, and $R$ refer to the growth, summer dormancy, and regrowth periods. 
Table 5. Air temperature and precipitation at the three sites for the period June 1 to October 31 during 1974 and 1975.

\begin{tabular}{|c|c|c|c|c|c|c|c|c|c|}
\hline \multirow[b]{2}{*}{ Measurement } & \multirow[b]{2}{*}{ Site } & \multirow[b]{2}{*}{ Year } & \multicolumn{6}{|c|}{ Month } & \\
\hline & & & May & Jun & Jul & Aug & Sept & Oct & \\
\hline & & & & & & & & & $\begin{array}{l}\text { Mean for } \\
\text { June to } \\
\text { September }\end{array}$ \\
\hline $\begin{array}{l}\text { Mean daily } \\
\text { maximum } \\
\text { temperature } \\
\text { (C) }\end{array}$ & $\begin{array}{l}\text { Opax Mountain } \\
\text { Poison Creek } \\
\text { Pass Lake }\end{array}$ & $\begin{array}{l}1974 \\
1975 \\
1974 \\
1975 \\
1974 \\
1975\end{array}$ & $\begin{array}{l}- \\
- \\
- \\
12 \\
14\end{array}$ & $\begin{array}{l}21 \\
15 \\
20 \\
16 \\
211^{1} \\
17\end{array}$ & $\begin{array}{l}21 \\
23 \\
20 \\
23 \\
22 \\
24\end{array}$ & $\begin{array}{l}24 \\
16 \\
22 \\
17 \\
25 \\
19\end{array}$ & $\begin{array}{l}19 \\
18 \\
19 \\
17 \\
20 \\
20\end{array}$ & $\begin{array}{r}\frac{10}{11} \\
\frac{1}{12} \\
8\end{array}$ & $\begin{array}{l}21 \\
18 \\
20 \\
18 \\
22 \\
20\end{array}$ \\
\hline $\begin{array}{l}\text { Mean daily } \\
\text { minimum } \\
\text { temperature } \\
\text { (C) }\end{array}$ & $\begin{array}{l}\text { Opax Mountain } \\
\text { Poison Creek } \\
\text { Pass Lake }\end{array}$ & $\begin{array}{l}1974 \\
1975 \\
1974 \\
1975 \\
1974 \\
1975\end{array}$ & $\begin{array}{l}- \\
- \\
- \\
\overline{0} \\
1\end{array}$ & $\begin{array}{l}7 \\
4 \\
6 \\
5 \\
5 \\
5\end{array}$ & $\begin{array}{r}8 \\
10 \\
7 \\
9 \\
7 \\
9\end{array}$ & $\begin{array}{r}11 \\
6 \\
8 \\
6 \\
8 \\
6\end{array}$ & $\begin{array}{l}8 \\
5 \\
5 \\
4 \\
4 \\
3\end{array}$ & $\begin{array}{r}2 \\
- \\
0 \\
-1 \\
0\end{array}$ & $\begin{array}{l}8 \\
6 \\
6 \\
6 \\
6 \\
6\end{array}$ \\
\hline & & & & & & & & & $\begin{array}{l}\text { Total } \\
\text { June to } \\
\text { October }\end{array}$ \\
\hline $\begin{array}{l}\text { Total } \\
\text { rainfall } \\
(\mathrm{cm})\end{array}$ & $\begin{array}{l}\text { Opax Mountain } \\
\text { Poison Creek } \\
\text { Pass Lake }\end{array}$ & $\begin{array}{l}1974 \\
1975 \\
1974 \\
1975 \\
1974 \\
1975\end{array}$ & $\begin{array}{l}- \\
- \\
- \\
3 \\
-\end{array}$ & $\begin{array}{l}2 \\
5 \\
2 \\
5 \\
1 \\
6\end{array}$ & $\begin{array}{l}4 \\
2 \\
5 \\
2 \\
4 \\
2\end{array}$ & $\begin{array}{l}4 \\
5 \\
2 \\
4 \\
2 \\
5\end{array}$ & $\begin{array}{l}1 \\
0 \\
2 \\
0 \\
1 \\
0\end{array}$ & $\begin{array}{l}1 \\
4 \\
1 \\
8 \\
0 \\
7\end{array}$ & $\begin{array}{r}11 \\
18 \\
12 \\
19 \\
8 \\
20\end{array}$ \\
\hline
\end{tabular}

Occasionally monthly totals do not equal totals for the period June to October due to rounding error.

study was more likely due to favourable environmental conditions or plant health than to pinegrass possessing a high grazing resistance.

All measurements, yield $/ \mathrm{m}^{2}$, tiller height, and tiller number $/ \mathrm{m}^{2}$, revealed that treatment $\mathrm{H}_{6}$ was the most severe or one of the most severe (Tables 2 and 3). This is not surprising since treatment $\mathrm{H}_{6}$ involved the most intense and frequent clipping. Next to treatment $\mathrm{H}_{6}$, treatments $\mathrm{H}_{4}$ and $\mathrm{H}_{5}$ had the most severe effect on pinegrass vigor (Tables 2 and 3). Treatments $\mathrm{H}_{4}, \mathrm{H}_{5}$ and $\mathrm{H}_{6}$ were all clipped during the periods $\mathrm{G}$ and Ds. Treatment $\mathrm{H}_{3}$ had a small effect on vigor and occurred during the early part of period G. From the above results it would be concluded that pinegrass is sensitive to herbage removal cither during the latter part of period $G$ or during period Ds. Treatment $\mathrm{H}_{1}$, which had only a small effect on vigor occurred during the periods Ds and $R$. Thus it is the latter part of the period $G$ that is most sensitive to herbage removal and not the period Ds. Others (Stoddart and Smith 1955; Buwai and Trlica 1977a) have found that defoliation immediately after active growth and before the dry summer period or during the latter part of the growing season is most detrimental. The present results suggest that pinegrass is also susceptible to herbage removal during the mid-summer period when growth slows down and stops. In the Kamloops area this period occurs during the latter part of July.

Freyman (1970) recommended that pinegrass be grazed either from July to September or for 2 weeks in early June and then again in August. Since pinegrass appears to be most sensitive to grazing in July, Freyman's latter recommendation is the preferred. If fields must be grazed throughout July, they should be rested during July the following year.

Pinegrass yield depends upon treatment, tiller number

Table 6. Soil temperature at the three sites for the period June 1 to October 1 during 1975.

\begin{tabular}{|c|c|c|c|c|c|c|c|c|c|c|}
\hline \multirow[b]{2}{*}{ Site } & \multirow[b]{2}{*}{ Depth $(\mathrm{cm})$} & \multicolumn{9}{|c|}{ Observation date } \\
\hline & & Jun 1 & Jun 15 & Jul 1 & Jul 15 & Aug 1 & Aug 15 & Sept 1 & Sept 15 & Oct 1 \\
\hline Opax Mountain & $\begin{array}{l}10 \\
25 \\
50\end{array}$ & $\begin{array}{l}7.2 \\
7.2 \\
6.1\end{array}$ & $\begin{array}{l}7.2 \\
7.2 \\
6.7\end{array}$ & $\begin{array}{r}11.7 \\
10.6 \\
8.3\end{array}$ & $\begin{array}{l}11.7 \\
10.6 \\
10.0\end{array}$ & $\begin{array}{l}11.1 \\
10.6 \\
10.0\end{array}$ & $\begin{array}{r}10.0 \\
10.0 \\
9.4\end{array}$ & $\begin{array}{l}8.3 \\
8.1 \\
8.1\end{array}$ & $\begin{array}{r}10.0 \\
9.7 \\
9.4\end{array}$ & $\begin{array}{l}9.0 \\
8.6 \\
8.3\end{array}$ \\
\hline Poison Creek & $\begin{array}{l}10 \\
25 \\
50\end{array}$ & $\begin{array}{l}8.3 \\
7.2 \\
6.7\end{array}$ & $\begin{array}{l}7.8 \\
7.8 \\
7.2\end{array}$ & $\begin{array}{r}10.6 \\
8.9 \\
7.8\end{array}$ & $\begin{array}{r}11.1 \\
11.1 \\
9.4\end{array}$ & $\begin{array}{l}10.0 \\
10.6 \\
10.0\end{array}$ & $\begin{array}{c}10.0 \\
\overline{9} .4\end{array}$ & $\begin{array}{l}\frac{6.7}{7.8} \\
\end{array}$ & $\frac{10.5}{9.7}$ & $\frac{8.9}{-}$ \\
\hline Pass Lake & $\begin{array}{l}10 \\
25 \\
50\end{array}$ & $\begin{array}{r}10.6 \\
9.4 \\
8.3\end{array}$ & $\begin{array}{l}9.4 \\
9.4 \\
9.4\end{array}$ & $\begin{array}{l}13.9 \\
12.2 \\
10.6\end{array}$ & $\begin{array}{l}13.9 \\
13.9 \\
13.3\end{array}$ & $\begin{array}{l}12.8 \\
13.3 \\
13.3\end{array}$ & $\begin{array}{l}13.9 \\
10.6 \\
12.8\end{array}$ & $\begin{array}{l}10.0 \\
12.2 \\
10.6\end{array}$ & $\frac{12.2}{11.4}$ & - \\
\hline
\end{tabular}


and tiller height (size) as described by Equation 1. Because tiller number can explain 525 of the variability in yield adjusted for treatment and tiller height can explain only $12 \%$ of the variability in yield adjusted for treatment, tiller number may be a better measure of pinegrass production than tiller height. Tiller number detected in site $X$ treatment interaction whereas yield and tiller height did not. Since other studies (Sharrow and Wright 1977; Oswalt et al. 1959; Feltner and Massengale 1965) report that environmental conditions influence the effect of herbage removal on plant growth, it is expected that this interaction is real and that tiller number is a more useful measure of plant vigor. Tiller number would also be the preferred measure of pinegrass vigor and production in an actual grazing study since sequential counts can be made as grazing occurs. Yield and plant height could only be used by protecting the tillers from further grazing.

Tiller height, however, has two advantages over yield and tiller number as a measure of plant vigor. Tiller height was not dependent on initial tiller counts as were yield and tiller number. Thus tiller height can be utilized even when pinegrass cover is higher variable. Tiller heights (C.V. $=9 \%)$ were also less variable than yield $(\mathrm{C} . \mathrm{V} .=28 \%)$ or tiller number (C.V. $=28 \%)$. All three measurements, yield, tiller number and tiller height, are useful measures of effect of herbage removal on pinegrass vigor, since the rankings of the different treatments were approximately the same (Tables 2 and 3 ).

In conclusion, the environmental conditions and/or plant history at the time of herbage removal as well as the intensity of herbage removal determines the subsequent production of pinegrass. Pinegrass appears to be especially sensitive to herbage removal near the time of growth cessation in mid summer. The effect of herbage removal on pinegrass vigor can be evaluated by measuring either yield, tiller number or tiller height. With this knowledge of when pinegrass is most sensitive to herbage removal, grazing schemes must be established to maximize production as well as minimize plant injury.

\section{Literature Cited}

Branson, F.A. 1953. Two new factors affecting resistance of grasses to grazing. J. Range Manage. 6: 165-171.

Branson, F.A. 1956. Quantitative effects of clipping treatments on five range grasses. J. Range Manage. 9: 86-88.

Buwai, M., and M.J. Trlica. 1977a. Multiple defoliation effects on herbage yield, vigor, and total nonstructural carbohydrates of five range species. J. Range Manage. 30: 164-171.

Buwai, M., and M.J. Trlica. 1977b. Defoliation effects on root weights and total nonstructural carbohydrates of blue gama and western wheatgrass. Crop Sci. 17: 15-17.

Crider, F.J. 1955. Root-growth stoppage resulting from defoliation of grass. U.S. Dep. Agr. Technical Bull. 1102: 23 p.

Davidson, J.L., and F.L. Milthorpe. 1966. Leaf growth in Dactylis glomerata following defoliation. Ann. Bot. 30: 173-184.

Deinum, B. 1976. Photosynthesis and sink size: An explanation for the low productivity of grass swards in autumn. Neth. J. Agr. Sci. 24: 238-246.

Eck, H.V., W.G. McCully, and J. Stubbendieck. 1975. Response of shortgrass plains vegetation to clipping, precipitation and soil water. $\mathbf{J}$. Range Manage. 28: 194-197.

Feltner, K.C., and M.A. Massengale. 1965. Influence of temperature and harvest management on growth, level of carbohydrates in the roots, and survival of alfalfa (Medicago sativa L.) Crop Sci. 5: 585-588.

Freyman, S. 1970. Effects of clipping on pinegrass. Can. J. Plant Sci. 50: 736-739.

Gupta, S.K. 1977. Note on the efficiency of energy conserving capacity of three plots of grassland differing in clipping treatment. Indian J. Agr. Sci. 47: 111-113

Hides, D.H. 1978. Winter hardiness in Lolium multiflorum Lam. 1. The effect of nitrogen fertilizer and autumn cutting managements in the field. J. Br. Grassld Soc. 33: 99-105.

Leopold, A.C. 1949. Control of tillering in grasses by auxin. Amer. J. Bot. 36: $437-440$

Mueggler, W.F. 1972. Influence of competition on the response of bluebunch wheatgrass to clipping. J. Range Manage. 25: 88-92.

Oswalt, D.L., A.R. Bertrand, and M.R. Teel. 1959. Influence of nitrogen fertilization and clipping on grass roots. Soil Sci. Soc. Amer. Proc. 23: 228-230.

Sharrow, S.H., and H.A. Wright. 1977. Effects of fire, ash and litter on soil nitrate, temperature, moisture and tobosagrass production in the rolling plains. J. Range Manage. 30: 266-270.

SnedecorG.W., and KG. Cochran. 1967. Statistical Methods. 6th Ed. Iowa State Univ. Press. Ames, Iowa. 593 p.

Stoddart, L.A., and A.D. Smith. 1955. Plant Physiology in Relation to Grazing. p 102-103 in Range Management. McGraw-Hill, N.Y. 433 p.

Tisdale, E.W., and A. McLean. 1957. The Douglas-fir zone of southern British Columbia. Ecol. Monogr. 27: 247-266.

Trlica, M.J. 1977. Effects of frequency and intensity of defoliation on primary producers of arid and semi-arid rangelands In: The Impact of Herbivores on Arid and Semi-arid Rangelands. 2nd United States/Australia Workshop, Adelaide.

\section{Membership in the Society for Range Management. . .}

is open to those engaged in or interested in the study, management, or use of range ecosystems and the intelligent use of all range resources

includes research scientists, ranchers, governmental agency administrators and technical personnel, teachers, students, and people from the business community

provides members with two publications-one oriented to research (Journal of Range Management) and the other oriented to practical resource management (Rangelands) offers opportunities for face-to-face exchange of ideas at local, national, and intemational meetings of the Society.

Dues vary according to type of membership and geographical section. For application forms and additional information, contact the:

Executive Secretary

Society for Range Management

2760 West Fifth Avenue

Denver, Colorado 80204

(303) 571-0174 